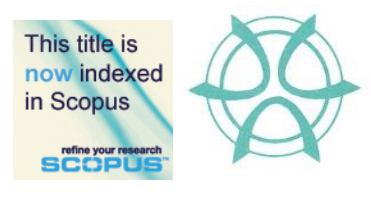

PLANNING MALAYSIA:

Journal of the Malaysian Institute of Planners

VOLUME 15 ISSUE 3 (2017), Page 147 - 158

\title{
A REVIEW ON OCCUPANTS' SATISFACTION AND WELLNESS LEVEL IN LOW-COST HOUSING IN MALAYSIA
}

\author{
Alice Sabrina Ismail ${ }^{1}$, Hazrina Haja Bava Mohidin², \& Muhammad Muhaimi \\ Daud $^{3}$ \\ ${ }^{1,2,3}$ Department of Architecture \\ UNIVERSITI TEKNOLOGI MALAYSIA
}

\begin{abstract}
The purpose of this study is to ascertain how architecture could impede stress level among low-cost housing occupants in Malaysia based on design implementations. The home environment is one of the main contributing factors for the occurrence of stress among occupants as much of individuals' lives are spent indoor. Based on this, architecture plays a major role in minimizing the stress level among occupants of a building. This research analyses the wellness of low-cost housing owners and occupants through observation and questionnaires that were distributed to low-cost housing residents. This study found that there are four key factors that contributed to stress among occupants. It is, therefore, hoped that the findings of this paper help designers to design better low-cost houses in order to provide a better living environment to the occupants.
\end{abstract}

Keyword: Low-cost housing in Malaysia; low-cost spatial design; occupants wellness; low-cost housing occupants

Date Received: $1^{\text {st }}$ November 2016

Date of Acceptance: $21^{\text {st }}$ October 2017 
Alice Sabrina Ismail, Hazrina Haja Bava Mohidin, \&Muhammad Muhaimi Daud

A Review On Occupants' Satisfaction and Wellness Level in Low-Cost Housing in Malaysia

\section{INTRODUCTION}

Low-cost housing projects in Malaysia have been one of the solution to cater the housing needs of urban B40. However, the poor design quality of these low-cost houses is becoming more apparent due to low prices and short construction period (Economic Planning Unit, 2010). Low-cost houses have also become less sensitive towards regional climate and residents' satisfaction and comfort.

Past researches on low-cost housing have touched on the safety and satisfaction of the residents and its sustainable adaptations. However, none of these discussed on the architectural design aspects especially in observing the spatial planning of a low-cost housing design and its influence on the wellness of the occupants.

This study, firstly, highlights the possible factors that cause disturbance and stress among residents of some of the existing low-cost housing. Later, design solutions that could maximize users satisfaction in living comfortably in a lowcost house are proposed.

\section{LOW-COST HOUSING IN MALAYSIA}

In Malaysia, a low-cost house must have a built-up of not less than 60 meter $^{2}$ and with a price range of RM25, 000.00- RM42, 000.00 per unit depending on the land cost. Low-cost houses are usually reserved for the lower income category or also known as the B40 household group (bottom $40 \%$ of the total Malaysian population). In a housing development project, the local planning authority may impose that $30 \%$ of the total unit of houses must be low-cost houses.

Low-cost houses are usually built on cheaper lands and designed to the minium standard of the Construction Industry Standard (CIS). In areas where land are scarce, such as Kuala Lumpur, low-cost houses are built vertically in stacks or also known as low-cost flats. In other areas where land is cheaper, low-cost houses may be built as landed properties.

A typical low-cost housing unit has very limited space that for only necessary functions at minimum standards suitable for human dwelling (Zaid \& Graham, 2011). A low-cost house usually comes with 2-3 bedrooms, 1-2 bathroom(s), a single unit of a kitchen, living room and dining area. Most of the low-cost houses have simple layout design. The spatial arrangement in a typical low-cost house usually begins with the entrance or doorway, which will then lead to the kitchen, living room, and bedrooms. Occupants would be connected to the toilet and dining area from these points onwards. The zonings in a low-cost house design comprise public and private areas. For the public area, most of the social interaction spaces such as the living room and dining area could be freely accessed by visitors, while the private areas such as the bedrooms, toilet and kitchen are spaces mainly for the residents. 


\section{LOW-COST HOUSING DESIGN AND ITS INFLUENCE TOWARDS OCCUPANTS' WELLNESS}

A healthy environment for a living starts from home. One of the most common problems that people are facing at home is stress. There are several factors that contribute to this problem. The first being the ergonomics of design layout and spatial arrangements in a house, insufficient green areas including landscaping and recreational area, compromised indoor comfort, and improper services and facilities area. As low-cost houses are built on a small budget, this affects the design, planning and construction of the houses. These four aspects have been discussed consistently but not simultaneously in all the Malaysian Plans even as early as during Tunku Abdul Rahman's era (Zaid \& Graham, 2011).

\section{The Ergonomics of Design and Spatial Arrangement in a Low-Cost House}

The term ergonomics in design often consider users' individual differences and their different characteristics, such as gender, age, and physical and mental conditions (Soares \& Rebelo, 2012). Architects, as the intermediary persons between clients and craftsmen, have the ultimate say in design decision-making process. They are, therefore, required to know who will be using the particular living space. As Rasdi et al. (2005) points out, house planning and design should consider the activity and functions to be held in the house. In planning and designing a house on a limited budget, architects must take note of the main spaces with regards to privacy, functions, and adaptability. Therefore, a good house should have a proper demarcation between the private and public, feminine and masculine and other internal boundaries (Munro \& Madigan, 1999). There should be an intermediate interface space that draws a line between these areas. The interface area should act as a link between private and public areas. Effective zoning could ensure the privacy of the occupants. It also gives an illusion of the termination of a public area to hinder visitors from entering into the private area.

A house designed for a family should also prioritize function and adaptability of a house, especially in a limited confined space. According to Munro \& Madigan (1999), a family home could turn out to be a prison and the locus of oppression, that frustrates home dwellers resulting in increase household complications such as an increase in divorce rate, depression among children and stressful lifestyle.

As put forth by Rasdi (2005), the open-plan concept, with various forms of physical and symbolic barriers are necessary for a house. This could be achieved by segregating guest zone in the front and family zone at the rear of the house whenever there are visitors. This type of zoning can be defined by space planning as well as creating different floor levels according to the function of the space (Rasdi et al., 2005). Apart from having spaces planned in such a manner, colors too play a significant role in decreasing the presence of household complications. Colors are known to lift up the mood of the occupants, thus 
Alice Sabrina Ismail, Hazrina Haja Bava Mohidin, \&Muhammad Muhaimi Daud

A Review On Occupants' Satisfaction and Wellness Level in Low-Cost Housing in Malaysia

resulting in a better family wellness (Herneoja, 2008).

\section{Compromised Indoor Comfort}

Indoor comfort is affected by openings and materials. There are three main roles of an opening. The first is to allow air into the building, second, it allows daylighting to penetrate into the house and, lastly, it frames the view.

An effective opening promotes air flow and air change rate (Lim, 2013).

This is to avoid hot air from being trapped inside the house and cause thermal discomfort among occupants of the building. As Malaysia is a country with hot and humid climate, adequate placement of openings throughout the house is seen crucial to maintaining a comfortable living among low-cost housing residents (Lim, 2013).

Openings also could avoid the usage of artificial lighting during the day. The size, placement and shading device applied on the opening control the amount of necessary day lighting penetrating the interior spaces (Lim, 2013; Zain-Ahmed et al., 2002). As Malaysia is blessed with abundance of sunshine throughout the day, maximizing daylighting as a source of natural lighting is seen as a great way in promoting sustainability. However, excessive day lighting especially caused by bad window placement could cause glare and this would cause discomfort to the dwellers (Lim, 2013). Designers are taught to minimize openings on the east and west-facing walls to avoid glare into the building. Adequate day lighting is important in the well-being of the occupant as too little and too much daylighting could cause stress and discomfort (Lim, 2013).

Windows frame exterior views. However, window design is crucial in a low-cost house as the houses are usually designed back-to-back to increase land use. Today's low-cost houses designers have ignored the importance of windows in promoting comfortable living space. Its placements should not be parallel with the ones that are being placed on the opposite house unit (Rasdi et al., 2005). Designers should design windows with regards to users privacy as improperly placed windows could invite intrusion of neighbours' view into private boundaries.

Materials used for house construction is also important. The right choice of materials could avoid the building wall from gaining heat (Muhammad Azzam \& Fahanim, 2011). This results in a milder indoor environment. Muhammad Azzam and Fahanim (2011) suggest that using natural building material obtained indegeniously could promote to better indoor comfort among home dwellers. However, this is seen impractical as natural material such as timber, bamboo or mud are far-reaching and their use in construction need skilled craftsmen. Since low-cost housing has a cost constraint, natural building material has never become an option for the developers.

Good quality building material is also required in order to ensure long lasting façade. This is important as low-quality material are more susceptible to 
PLANNING MALAYSIA

Journal of the Malaysia Institute of Planners (2017)

damage, and this leads to cracks and increases dampness in walls especially in Malaysia's hot and humid climate (Wahab, Khamidi \& Ismail, 2013). Damp and mouldy walls expose residents to sick building syndrome and cause discomfort to them.

\section{Insufficient Green Areas, Landscaping and Recreational Area}

Landscape is seen crucial in promoting healthy living (Bedimo-Rung, Mowen \& Cohen, 2005). Apart from providing comfortable living at home, the surrounding environment at the housing area is also important in promoting family wellness. Low-cost housing with limited land can take the initiative of turning the small unused land into pocket green spaces. These green spaces can provide recreational area especially for children around the low-cost neighbourhood apart from being the best place to ease stress (Godbey, 2009). A family could also spend more time outdoor at these pocket green parks doing recreational activities together to strengthen their family bond.

\section{Improper Service Area}

A properly managed housing area will not only sufficiently provide a wastedumping area, but it will also need to think of the best place to locate it (Subhan, Abdul Ghani \& Joarder, 2014). It is important that waste-dumping area cannot be left unattended as it could cause tremendous health concerns due to pests and vectors. The dumping area can also be an eye-sore if placed at prime location in the housing area. Thus, it is best kept far from the main entry point of the housing area. It should, however, be accessible to all residents. The best place to provide waste-dumping area would be at the rear of the housing are plot. This would ensure that the waste-dumping area is kept hidden, away from public view while accessible by waste collecting trucks. This is to ensure a better living environment for the nearby residents (Abu Eusuf et al., 2011)

\section{METHODOLOGY}

This research will be using multiple case study method where observation and dichotomous close-ended questionnaire with the residents will be done in parallel. Interpretivism paradigm was chosen as the research method as it involves researchers and the residents to interpret elements. It is, therefore, encouraging human involvement into the study of interpretation. Semiotic is paired with interpretivism as it involves the study of meaning and sign (Mohidin \& Ismail, 2015). This proposed methodological framework is considered as an important contribution as it introduces new ways of looking at low-cost houses as a system of 'sign' as well as proposing various indicators in order to investigate this matter in depth. This study builds upon the theories and concepts outlined by Saussure on sign relations, Barthes on levels of signification, and Gottdiener on reading the material culture as reliable ways for analysing and understanding the 
Alice Sabrina Ismail, Hazrina Haja Bava Mohidin, \&Muhammad Muhaimi Daud

A Review On Occupants' Satisfaction and Wellness Level in Low-Cost Housing in Malaysia

residential building (Ismail, 2008).

\section{FINDINGS}

For this study, Taman Dagang Jaya Flats was chosen as the case study. Taman Dagang Jaya Flats is a low-cost flat located in Ampang, Selangor. The area was developed over 25 years ago. Units were sold at RM25,000 when they were first opened to the public. Now, the value of Taman Dagang Jaya Flat has doubled. Due to its strategic location and easily accessible by Light Rail Transit (LRT), it has been one of the fastest selling low-cost flat in Selangor.

\section{Design and Spatial Arrangements}

Taman Dagang Jaya Flats is a cluster of a ten blocks of low-cost flats. All the blocks are four storey walk-up flats. Each unit of the house is made up of $650 \mathrm{sqft}$ of floor area, comprising two bedrooms, one shared toilet, a kitchen, a living room, and a dining area. Units on the ground floor have an alternative entrance that is directly connected to the the corridor from the kitchen. Meanwhile, for units on the upper floors, this space is reserved for laundry activities and has no direct access from the corridor to ensure safety and security.

Based on observation of the design layout, the spaces are zoned accordingly with a guest zone in front and family zone at the rear of the house whenever there are visitors to the house. However, the toilet is placed too far away from the bedroom and home dwellers need to by-pass the living room and kitchen to utilize the toilet. This is seen as a very stressful design feature as the toilet is not freely accessible and spaces are not demarcated based on comfort and gemder boundaries. The corridor is also too narrow, making it an uncomfortable for the homeowners to open their doors as the main entrances are too close to one another at only approximately 1.2 meters apart.

\section{Indoor Comfort}

As for the indoor comfort, all of the rooms have louvered window panes that can be tilted according to the needs of day lighting and air flow into the house. It is also noticeable that the kitchen has ample openings to ensure sufficient natural ventilation. As Taman Dagang Jaya Flat is a low-cost housing, it is unavoidable to see the usage of modern construction materials especially on the envelope of the building as natural material is impossible due to its cost and maintenance.

\section{Green Areas, Landscaping and Recreational Area}

Green areas and recreational areas are provided at the flats. Although the landscape area may not be properly designed, at least the residents still have ample outdoor space for recreational purposes. Additionally, children's playground and a football field were also provided. In the afternoon, these areas are flocked by children and youths from the flats for outdoor recreation. 
PLANNING MALAYSIA

Journal of the Malaysia Institute of Planners (2017)

\section{Service Area}

From observation, it was apparent that the placement of the waste-dumping site is taken for granted. In a recent report, the residents of Taman Dagang Jaya Flat expressed their concern towards health and cleanliness of their housing area, and demanded the local authority to take action for a change. The residents also feel that waste-dumping facilities need upgrading to help improve the living condition in the flats.

\section{Residents Satisfaction Level}

60 respondents at Taman Dagang Jaya Flats were selected as sample for the perception survey to gauge residents satisfaction level of their housing area and how it affects their family wellbeing. The respondents were asked based on the four categories; design and space arrangements, indoor comfort, green areas, landscape and recreational area and service area. The results of the questionnaire are outlined as below:

a. Design and space arrangements

1.Do you feel stress at home?

2. When at home, do the spaces contribute to the level of your stress?
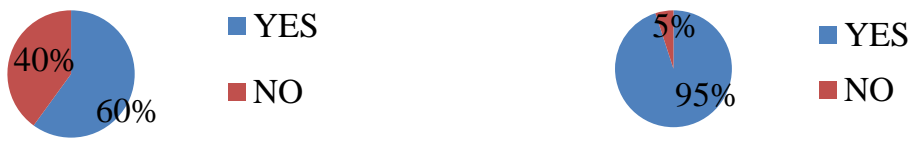

3.Do you feel that the spaces provided in the house a little cramped and inadequate in its size?

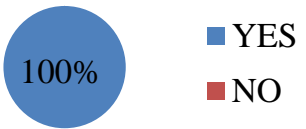

4.Does your unit have openings that are exposed to unpleasant views?

5.Does your unit have openings that are too close to your neighbour?

6.Does the presence of neighbors contribute to the level of your stress?
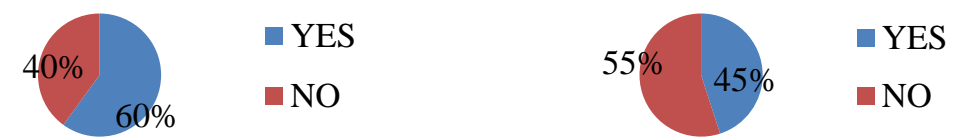
Alice Sabrina Ismail, Hazrina Haja Bava Mohidin, \&Muhammad Muhaimi Daud

A Review On Occupants' Satisfaction and Wellness Level in Low-Cost Housing in Malaysia

7. Do you think the color of the building is dull and causing stress among residents?

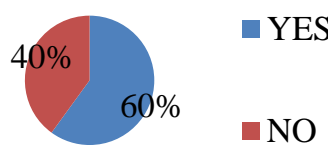

b.Indoor comfort

1.Is your house naturally lit during the 2.Is there sufficient air flow that day? cools the house?
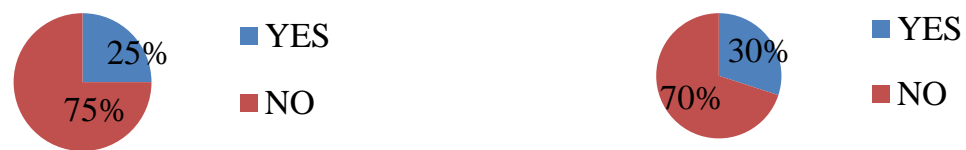

3. Are there any serious cracks on your walls that lead to dampness and moulds?

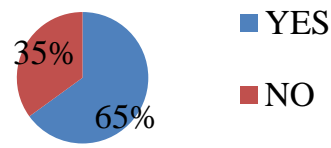

c. Green areas, landscape and recreational areas

1.Are there ample green areas for 2.Is there a playground provided for recreational purposes? the children?
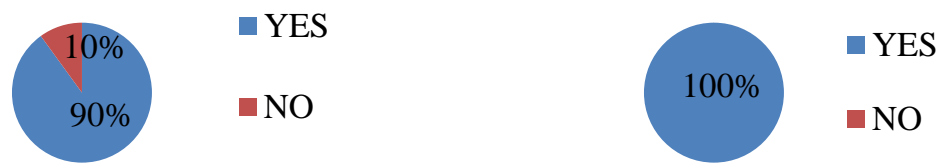

3. Do you think that the living environment you are currently in is affecting your health and stress level?

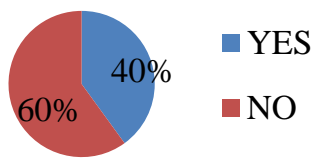


PLANNING MALAYSIA

Journal of the Malaysia Institute of Planners (2017)

d. Service area

1.Are the services provided at your 2.Is the waste-dumping area located residential area sufficient? appropriately?
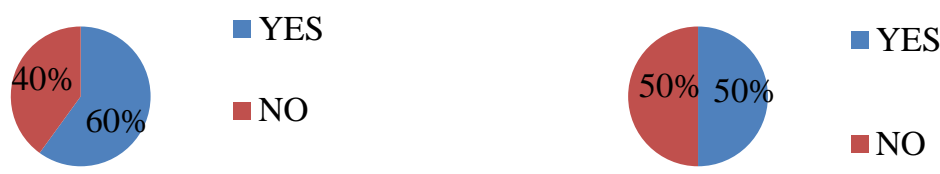

3. Do you think an upgrade to some of the services is needed to ensure healthier and cleaner lifestyle?

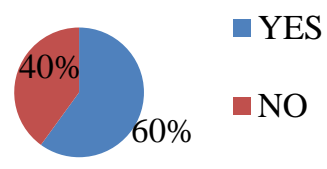

\section{DISCUSSION}

With reference to the above analysis, most residents felt that the interior spaces of their home were insufficient. The lack of personal space meant that most of the time residents have to share their spaces with everyone in the household. Apart from that, the intrusion of neighbours' view into the house has led to serious privacy issue, which in turn, caused most homeowners to avoid opening their main door at most of the time. This led to lack of indoor comfort as they could not make full use of the openings in order to have effective ventilation and adequate natural day lighting.

More than $50 \%$ of the residents had noticed the formation of moulds on walls. This could be due the use of lower quality construction materials. The presence of dampness and moulds could lead to serious health problems and uncomfortable living.

The residents were also aware of their surrounding condition as much as they are concern with their personal housing units. This was because it has become more and more apparent that the surrounding living environment needed attention and upgrade by the local authority. This was due to insufficient dumping bins, and dirty waste-dumping facility.

The residents were satisfied with the green areas and recreational areas provided for them. The residents were aware of the importance of properly managed, healthy and clean living environment as the key factor to a good family wellbeing. 
Alice Sabrina Ismail, Hazrina Haja Bava Mohidin, \&Muhammad Muhaimi Daud

A Review On Occupants' Satisfaction and Wellness Level in Low-Cost Housing in Malaysia

\section{RECOMMENDATIONS}

Based on the findings from the observation and survey conducted, below are some guidelines in promoting wellness level while decreasing stress level:

i. To increase the percentage of personal space which can be turned into multi-functional spaces or flexible space - this is to avoid wastage of space while having sufficient personal space for individual wellness;

ii. To introduce the usage of sustainable and long lasting materials that are harmless to the environment; and

iii. To increase green spaces including designs of courtyards and stairwells for natural ventilations to increase air flow and maximize daylighting.

\section{CONCLUSION}

From the above study, it is clearly noted that all of the categories except green, landscape, and recreational areas, contributed to the level of stress and wellbeing of the residents at Taman Dagang Jaya Ampang. Design and spatial arrangement of the houses were found to be the main reasons. Insufficient space was provided in the unit and there was no special area in the unit that promotes personal space due to space requirement constraint. These two elements should be given attention by the government and the designers of low-cost houses so that residents of low-cost houses can enjoy a more stress-free living environment. 


\section{REFERENCES}

Abu Eusuf, M., Ibrahim, M., Din, S. A. M., \& Islam, R. (2011). Solid waste generation characteristics: The Malaysian local authorities' outlook. Planning Malaysia, 9, 51-76.

Bedimo-Rung, A. L., Mowen, A. J., \& Cohen, D. A. (2005). The significance of parks to physical activity and public health: a conceptual model. American Journal of Preventive Medicine, 28(2), 159-168.

Godbey, G. (2009). Outdoor recreation, health, and wellness: Understanding and enhancing the relationship. RFF Discussion Paper No. 09-21.

Herneoja, A. (2008). The cheerful aspects of colouration of home: Children's Rooms and Kitchens during the post-war reconstruction period. Department of Architecture, University of Oulu, Finland.

Ismail, A. S. (2008) A multidisciplinary approach in understanding the symbolic meaning of built form. Methodology in Architectural Research (pp. 180211). Johor: Penerbit UTM.

Lim, Y. W. (2013). Indoor environmental comfort in Malaysian urban housing. American Journal of Environmental Science, 9(5), 431-438.

Malaysia. Economic Planning Unit. (2010). Tenth Malaysia Plan 2011-2015. Putrajaya: The Economic Planning Unit, Prime Minister's Department

Muhammad Azzam, I., \& Fahanim, A. R. (2011). Smart and cool home in Malaysia. Advanced Materials Research, 224, 115-119.

Munro, M., \& Madigan, R. (1999). Negotiating space in the family home. In I. Cieraad (Ed.), At home: An anthropology of domestic space (pp. 107117). Syracuse: Syracuse University Press.

Mohidin, H. B. H. B., \& Ismail, A. S. (2015, January). Regional design approach in designing climatic responsive administrative building in the $21 \mathrm{st}$ century. In IOP Conference Series: Earth and Environmental Science, 23(1), 12-16. IOP Publishing.

Rasdi, M. T. M., Mohd Ali, K., Syed Ariffin, S. A. I., Mohamad, R., \& Mursib, G. (2005). The architectural heritage of the Malay world: The traditional houses. Skudai: Penerbit UTM.

Soares, M. M., \& Rebelo, F. (2012). Ergonomics in design: solutions and proposals for a better interface with the user. Theoretical Issues in Ergonomics Science, 13(1), 1-3.

Subhan, M., Abdul Ghani, A. B., \& Joarder, M. H. R. (2014). Urban community willingness to pay for improved solid waste management in a Malaysian municipality: A choice modeling approach. Asian Social Science, 10(18), 122-136.

Wahab, A. N. S., Khamidi, M. F., \& Ismail, M. R. (2013, April). An Investigation of mould growth in tropical climate buildings. In Business Engineering and Industrial Applications Colloquium (BEIAC), 2013 IEEE (pp. 316321). IEEE. 
Alice Sabrina Ismail, Hazrina Haja Bava Mohidin, \&Muhammad Muhaimi Daud

A Review On Occupants' Satisfaction and Wellness Level in Low-Cost Housing in Malaysia

Zaid, N. S. M., \& Graham, P. (2011). Low-cost housing in Malaysia: A contribution to sustainable development? Proc., Energy, Environment and Sustainability. DOI: 10.13140/RG.2.1.2715.9120.

Zain-Ahmed, A., Sopian, K., Othman, M. Y. H., Sayigh, A. A. M., \& Surendran, P. N. (2002). Daylighting as a passive solar design strategy in tropical buildings: a case study of Malaysia. Energy Conversion and Management, 43(13), 1725-1736. 